\title{
A Conceptual Approach to Identify Factors Affecting the Digital Transformation of Micro, Small and Medium-sized Enterprises (MSMEs) during Covid-19 Pandemic in Indonesia
}

Ruly Wiliandri $\mathbf{i}^{1,2}$

${ }^{1}$ Leiden Ethno-systems and Development Programme (LEAD), Leiden University, The Netherlands ${ }^{2}$ Department of Management, Faculty of Economics, State University of Malang, Malang, Indonesia

\begin{tabular}{l} 
Info Article \\
\hline History Article: \\
Submitted:06 October 2020 \\
Revised:16 November 2020 \\
Accepted:29 December 2020 \\
Keynords: \\
Digital Transformation (DT); \\
Factors; Micro, Small, and \\
Medium-sized Enterprises \\
(MSMEs); Capability \\
Perspective; Ecosystem \\
Perspective
\end{tabular}

\section{Abstract}

This article aims to identify both internal and external factors that influence the Digital Transformation (DT) process of Micro, Small, and Medium-sized Enterprises (MSMEs) during the COVID-19 pandemic. The Covid-19 pandemic, which hits all countries including Indonesia, forces business entities, including MSMEs, to digitally transform their business process. The government's policies on physical distancing and Large-Scale Social Restriction in several regions greatly impacts MSMEs' activities i.e. decreasing demands or sales up to $60 \%$. The government's support for improving the telecommunications infrastructure and a digital ecosystem plays an essential role in accelerating DT. Besides, the government's initiative to establish business centers can also promote DT of the MSMEs. Moreover, this article describes the challenges faced by MSMEs in carrying out DT during the pandemic. This article applied a conceptual approach to explore the influential factors, both internal and external factors of DT process for MSMEs. Besides, this article will explain DT of MSMEs based on capability and the ecosystem perspectives. As this article suggests, considering those factors will broaden our understanding of MSMEs' efforts to digitalise their business. The digital transformation model via business centers establishment can encourage MSMEs to go digital.

\section{Pendekatan Konseptual untuk Mengidentifikasi Faktor Faktor yang Mempengaruhi Transformasi Digital Usaha Mikro Kecil Dan Menengah (UMKM) di Masa Pandemi Covid-19 di Indonesia}

\begin{abstract}
Abstrak
Artikel ini bertujuan untuk. mengidentifikasi faktor-faktor baik internal maupun eksternal yang dapat mempengarubi proses Transformasi Digital (TD) pada Usaha Mikro Kecil dan Menengah (UMKM) di tengah pandemi Covid-19. Pandemi Covid-19 yang melanda di semua negara, termasuk Indonesia, menuntut semua pelaku usaha termasuk. UMKM untuk segera melakukan TD. Kebijakan pemerintah tentang physical distancing maupun Pembatasan Sosial Berskala Besar (PSBB) di beberapa wilayah di Indonesia mempunyai dampak pada aktivitas UMKM, terutama penurunan permintaan atau penjualan sampai lebih dari 60 persen. Dukungan dan kerjasama dari semua pihak, termasuk pemerintah dalam meningkatkan jaringan infrastruktur telekomunikasi serta membentuk ekosistem digital diperlukan untuk mendorong percepatan digitalisasi pelaku UMKM. Selain itu, pembentukan sentra-sentra bisnis UMKM diharapkan akean memudabkan pemerintah dalam mempercepat upaya digitalisasi pelaku UMKM. Artikel ini juga akan memaparkan tantangan yang dihadapi UMKM dalam melakukan transformasi digital di masa pandemi. Artikel ini menggunakan pendekatan konseptual atau biasa dikenal conceptual approach tentang faktor-faktor yang mempengarubi proses TD bagi UMKM, yang dikelompokkan menjadi faktor internal dan eksternal. Artikel ini juga akan menggambarkan dan menjelaskan TD yang dilakukan UMKM berdasarkan dua perspektif yaitu perspektif kemampuan (capability perspective) dan perspektif ekosistem (ecosystem perspective). Sebagaimana saran artikel ini, perbatian terhadap faktor-faktor tersebut akan membantu kita memahami upaya UMKM dalam melakukan digitalisasi bisnis di tengah pandemi. Model TD dengan memfokuskan pada sentra bisnis UMKM dibarapkan dapat mendorong dan meningkatkan pelaku UMKM untuk go-digital.
\end{abstract}

How to Cite: Wiliandri, R. (2020). A Conceptual Approach to Identify Factors Affecting the Digital Transformation of Micro, Small and Medium-sized Enterprises (MSMEs) During Covid-19 Pandemic in Indonesia. Ekonomi Bisnis, 25 (2), 66-85

Correspondence Address
Institutional address: FE Universitas Negeri Malang, Jl. Semarang 5 Malang

E-mail: r.wiliandri@science.leidenuniv.nl/ruly.wiliandri.fe@um.ac.id
0853-7283 (print) 2528-0503 (online) DOI: $10.17977 /$ um042v25i2p66-85 
Coronavirus $(\mathrm{CoV})$ pandemic, known as COVID-19, greatly influences all nations' economic activities. Before being declared as a pandemic, in early 2020, the World Health Organization (WHO) accepted reports on a breakout of a pneumonia cluster in Wuhan, Hubei province, China, on December 31, 2019 (Kemenkes, 2020). On January 13, 2020, the first case outside of China was reported in Thailand. The case confirmed a Wuhan citizen suffered from the disease (WHO, 2020; Hinjoy, Tsukamaya, Chuxnum \& Masunglong, 2020). The rapid spread of the virus and increasing number of contracted persons to the virus requires the $\mathrm{WHO}$ to announce that COVID-19 is a global pandemic on March 11, 2020 (Kemenkes, 2020). In Indonesia, President Joko Widodo, officially announced two confirmed COVID-19 cases on March 2, 2020 (Kemenkes, 2020). John Hopkins University (2020), an institution providing COVID-19 data source worldwide, reported that on August 8, 2020, COVID-19 had spread to 188 countries with total cases of 19,406,765 and a mortality rate of 722,066 victims. On the other hand, Indonesia's COVID-19 cases have noted 123,503 cases with a mortality rate of 5,658 victims (based on the data per August 8, 2020).

The Indonesian government has made numerous efforts to suppress the virus spread; one was applying Large-Scale Social Restriction, Physical Distancing, and Work and Learn from Home. These restrictions on several regions in Indonesia impacted all life aspects, such as health, social, economy, and financial. Firstly on the health aspect, the rapid spread of COVID19 triggered critical health issues indicated by lack of health facilities and infrastructures, especially the medical workers to handle the confirmed COVID19 patients. Another issue is the provision of COVID-19 detectors, such as rapid test or Polymerase Chain Reaction (PCR) provided by the government (Djalante, Lassa, Setiamarga, \& Sudjatma, 2020). Besides, the other impacts are increasing demands on medical tools and equipment, such as masks, personal protectors, hand sanitizers, etc. Second, in terms of social aspect, both social and physical distancing policies impacted on the decrease or even termination of economic activities, especially those working in the informal sector (Bagus, Arif, Fathin, \& Ranggajati, 2020). In addition, many employment terminations also potentially increased unemployment rates which impacts the community's poverty level (Bagus et al., 2020; Suryahadi, Izzati, Suryadarma, 2020). In terms of economic aspect, it impacts supply and demand (Guerrieri et al., 2020). However, the COVID-19 pandemic lowers consumption sectors, decreasing number of travels and people's mobilization, and increasing transportation and sales costs. The restrictions due to COVID-19 impact on the productivity of employees and laborers, decreasing investment and funding activities, and interrupted manufacturing sectors' global supply chains, such as contracted export-import activities (Damuri \& Hirawan, 2020). Financially, a decrease is experienced by real sector performance because of decreasing business volumes and production capacities. The other impacts on the financial sector are non-performing loans, profitability, liquidity, and solvency (Kemenkeu, 2020).

Previously, Indonesia experienced economic crises in 1998, known as the Asian Financial Crisis, and in 2008, the Global Financial Crisis. Many large 
corporations went bankrupt during the crises. Banking industries also experienced the impact due to large corporations' payment disruption. The capital market was also impacted by the Global Financial Crisis in 2008 (Bank Indonesia, 2010). Back then, Micro, Small, and Medium-sized Enterprises (MSMEs) could survive the condition and even be at the stake to promote economic recovery during the crisis. On the contrary, an economic crisis which is initially caused by a health crisis, the COVID-19 pandemic in Indonesia massively impacted all business from retailers, consumers, MSMEs, and even corporate levels.

Some other sectors were also impacted due to decreasing demands for domestic, exports, and even imports because of restrictions on production activities in various industrial groups such as manufacturing, selling, accommodation, food and beverage, transportation, warehouse, and tourism due to decreasing number of visits (Kemenkeu, 2020). Therefore, the government has to make several attempts to stabilize the economy. Important to note that performance of three service sectors have significantly improved during the pandemic. For example, the sector of information and communication due to changes in people's activity where most people work and school from home. In addition, financial and insurance sectors also experience improvement due to increasing uses of electronic money platforms and internet banking as a response to physical distancing. More importantly, the health sector needs to improve its services to deal with COVID-19 exposed patients.

As mentioned above, MSMEs may be able to survive better than other sectors during the crises in 1998 and 2008. However, the current crisis due to the COVID-19 pandemic is different. It provides different challenges for MSMEs to sustain their business due to social and physical distancing policies, i.e. Large-Scale Social Restriction in several regions that disrupt MSMEs. Thus, MSMEs are hindered from both demand and supply sides. Based on the data of the Ministry of Cooperation and Small and Medium Enterprises, there are five main problems faced by most MSMEs: decreased sale and demand, rare raw materials, hindered distribution or operation, capital difficulties, and hindered production (KemenkopUKM, 2020).

The MSMEs' sustainability during this pandemic may be important for Indonesia to be able to recover its economy since many businessmen in Indonesia are in micro, small, and medium sectors. Besides, the recruitments of employment in the MSMEs sector are significant. Based on the data of The Ministry of Cooperation and Small and Medium Enterprises or KemenkopUKM (2018), the number of businessmen in the micro sector reaches $98.68 \%$, with $89.04 \%$ employment. On the other hand, small and medium businessmen are only up to $2 \%$, with $5 \%$ employment whereas large scale businessmen has only $0.01 \%$ with $3 \%$ employment. Based on the rates, the roles of MSMEs can be seen as significant in the national economy. Therefore, the numbers of businessmen or employment in Indonesia's micro sector may be susceptible to interruption, especially due to the COVID-19 pandemic. The pandemic also impacts on the restrictions of the promotions on economic activities. The decreasing demand leads to decreasing purchase rate due to low 
incomes which maybe because of unemployment or disruption, such as pandemic. The pandemic condition requires the government to issue policies, such as Large-Scale Social Restriction in several regions, physical distancing, or work from home. Therefore, businessmen have to adapt and transform quickly so that their businesses will survive.

Based on Indonesia's data of MSMEs, the commercial sector dominates $46.17 \%$ with $31.81 \%$ employment rate (BPS, 2018). The commercial sector improves quickly due to digital technology encouragement facilitating consumers to purchase goods online. The consumers also have easier access to compare products' prices and qualities prior purchase. However, many MSMEs owners in the commercial sector may not have business skills that enable them to keep up with digital technology advancement. It is evident during the pandemic. Many MSMEs experience decreasing demands up to $60 \%$ compared to normal conditions (KemenkopUKM, 2020).

To survive the pandemic, MSMEs need not only innovative and creative business management but also proper production strategy, selling, and marketing processes. Digital transformation may be a viable solution for MSMEs during this COVID-19 pandemic to keep up the business, create added values, and expand their market share. In the digital transformation process, Information Technology (IT) skill is necessary to encourage MSMEs to prepare their business and resources to go digital. As shown by results in some research, one of the main identified factors that influence corporatefinancial performance is information technology through the digitalisation of Small Medium-sized Enterprises (SMEs) (Nguyen, 2015; Eller, 2020).

This article aims to identify the crucial factors influencing the digital transformation of MSMEs based on capability and ecosystem perspectives. This article also attempts to identify required internal factors and encouraging external factors of MSMEs' necessities to promote their business digitally. This article will start with explaining digital transformation phenomena and its challenges for MSMEs, especially during this COVID-19 pandemic. Then, the identification of influential digital transformation factors will follow-it also will be elaborated based on capability and ecosystem perspectives. Moreover, this article will develop a digital transformation model based on business centres in specific MSMEs. Hopefully, the pattern of MSMEs grouping in business centres will make it easier for the government to encourage MSMEs digitalisation.

The digital transformation process by MSMEs requires multidisciplinary science. Thus, by involving all concerned science disciplines, a more holistic understanding about why, how, and when digital transformation may work and is needed will be gained. Eventually, interdisciplinary research will help every related party make appropriate and strategic decisions, such as skills to respond to digital technology and apply the digital transformation. Thus, an integrated effort from all parties, both government, micro, small, and medium, and large businessmen, are needed to create a sustainable MSMEs business. Thus, it can accelerate the National Economic Recovery or Pemuliban Ekonomi Nasional (PEN). 


\section{RESEARCH METHOD}

The applied research method was the qualitative method with a conceptual approach or known as a literature research. This research was done by observing and analyzing information from a wide variety of references with a certain topic. This research dealt with either conceptual or abstract ideas. This research uses a conceptual framework, a combination of researchers from the relevant previous studies and an explanation of the on-going phenomena. Jaakkola (2020) proposed four conceptual article design types: theory synthesis, theory adaptation, typology, and model.

On the other hand, the research design used is a theoretical framework development model that predicts the correlation between notions or concepts. It starts from a phenomenon and continues by searching several literatures describing main elements of the explained phenomenon or concept. Eventually, it reaches the theory that explains the correlations among the investigated variables (Jaakkola, 2020).

Several stages taken to create the conceptual research framework are: (1) choosing the research topic, (2) collecting the relevant literatures and information of the conceptual research based on the previous studies, (3) identifying specific variables concerning the research, and (4) creating a framework by using variables obtained from scientific articles and related materials. This article investigates topics focused on digital transformation by MSMEs by collecting literature and information from relevant previous studies to identify influential factors of digital transformation toward the MSMEs. Then, it will be the variables of framework and also predict correlations among variables.

\section{FINDINGS AND DISCUSSIONS}

The General Descriptions of Indonesia's MSMEs: Their Conditions Related to Digital Transformation and their Challenges during COVID-19 Pandemic

The COVID-19 pandemic significantly impacts the sustainability of MSMEs in almost all sectors. It is specifically for the commercial sector that dominates almost $50 \%$ of MSME businesses. Before the pandemic breakout, MSMEs can rely only on their offline sales. However, due to the pandemic and the policies of physical distancing, work from home (WFH), or Large-Scale Social Restriction in several regions, it requires MSMEs to immediately adapt to the consumers'/markets' demands.

The Bank of Indonesia (BI) claims that COVID-19 put pressure on the country's economy as can be seen in the decrease of the economy in Indonesia (in 2020). However, the BI is optimistic that Indonesia's economy will be recovered in 2021 (BI, 2020). Based on the expenses in Gross Domestic Product (GDP), household consumption, annually, contributes the greatest to Indonesia's economy in total. It was $56.62 \%$ contribution in 2019.

On the other hand, in the first quarter of 2020, the household consumption expenditure showed an increased percentage of $58.12 \%$. However, in the second quarter, it decreased by a percentage of $57.85 \%$ due to COVID-19 impacts. The percentage of household consumption components reached 50\% higher on GDP which shows that the economy in Indonesia was mostly based on domestic consumption. Table 1 shows the GDP in between 2018 and the second quarter of 2020 . 
Table 1. GDP based on the Current Prices according to the Expenditure of 2018, 2019, First and Second Quarters of 2020 (Trillion rupiahs)

\begin{tabular}{|c|c|c|c|c|}
\hline \multirow{2}{*}{$\begin{array}{c}\text { Types } \\
\text { Expenses }\end{array}$} & \multirow[b]{2}{*}{2018} & \multirow[b]{2}{*}{2019} & \multicolumn{2}{|c|}{2020} \\
\hline & & & $\begin{array}{c}\text { First } \\
\text { Quarter }\end{array}$ & $\begin{array}{l}\text { Second } \\
\text { Quarter }\end{array}$ \\
\hline Household Consumption & $8,274.2$ & $8,965.8$ & $2,280.0$ & $2,133.5$ \\
\hline $\begin{array}{ll}\text { Non-Profit } & \text { Institution } \\
\text { Serving } & \text { Household } \\
\text { Consumption } & \\
\end{array}$ & 180.8 & 206.0 & 50.2 & 50.0 \\
\hline $\begin{array}{l}\text { Government } \\
\text { Consumption }\end{array}$ & $1,336.6$ & $1,385.9$ & 254.9 & 319.6 \\
\hline $\begin{array}{l}\text { Gross Fixed Capital } \\
\text { Formation }\end{array}$ & $4,789.4$ & $5,119.5$ & $1,251.7$ & $1,128.8$ \\
\hline Inventory Changes & 338.6 & 226.9 & 88.3 & 120.7 \\
\hline Statistics Discrepancy & 75.6 & 7.2 & 3.5 & -70.8 \\
\hline Good \& Service Exports & $3,111.9$ & $2,914.6$ & 683.2 & 578.4 \\
\hline Good \& Service Imports & $3,268.8$ & $2,992.0$ & 689.1 & 572.5 \\
\hline GDP & $14,838.3$ & $15,833.9$ & $3,922.7$ & $3,687.7$ \\
\hline
\end{tabular}

Source: BPS (2020)

Table 1 shows that the GDP in Indonesia mostly originated from domestic consumption. Interestingly, MSMEs also significantly contribute to GDP gain, with almost $60 \%$. Based on the Ministry of Cooperation and SME data (2018), 99\% of the MSMEs entrepreneurs can recruit up $97 \%$ workforces, which has a higher rate than the counterparts, large scale businessmen. However, many micro, small, and medium businessmen lack financial support from the bank where only $20 \%$ of MSMEs obtain banking funding. On the other hand, the large businessmen received $80 \%$ of their funding from banks. Table 2 shows the percentages of Large Business (LB) and MSMEs on Indonesia's economy in 2018.

Table 2. The Contribution Percentage Data of LB and MSMEs for Economy in Indonesia

\begin{tabular}{lcccc}
\hline Enterprises Scale & $\begin{array}{c}\text { Composition of } \\
\text { Entrepreneurs }\end{array}$ & $\begin{array}{c}\text { Recruited } \\
\text { Workforces } \\
\text { Employed }\end{array}$ & $\begin{array}{c}\text { Contributions } \\
\text { toward GDP }\end{array}$ & $\begin{array}{c}\text { Banking Funding } \\
\text { Distribution }\end{array}$ \\
\hline Large Business (LB) & $0.01 \%$ & $3 \%$ & $40 \%$ & $80 \%$ \\
\hline $\begin{array}{l}\text { Micro, Small, and } \\
\text { Medium Enterprises }\end{array}$ & $99.99 \%$ & $97 \%$ & $60 \%$ & $20 \%$ \\
\hline Source: The Ministry of Cooperation and Small and Medium Enterprises (2018)
\end{tabular}

The Micro and Small Enterprises (MSEs) in Indonesia mostly have informal characteristics. They typically do not have a legal entity and a proper financial statement system. These influence the business financial reports, capital and skill limitation, and limited technology usages. Based on the data of the Central Bureau of Statistics (BPS) (2018), from the data of the Economic Census in 2016 (SE2016extended), most MSEs were not legally enticed $(93.45 \%)$ which influenced the 
banking-funding for MSEs and therefore they have to manage with limited capital. Dealing with technological usages, $93.78 \%$ of MSEs have not used computers while 90.24\% have not used the internet. The partnership between MSEs and Large Enterprises was still limited, only 7\% (BPS, 2018). In addition to those limitations, MSEs also faced problems to run their businesses, such as domination by competitor $(60.53 \%)$, capital or liquidity problem (60.14\%), marketing problem $(33.04 \%)$, raw material or commodity procurements $(14.36 \%)$, and infrastructure $(7.79 \%)$ (BPS, 2018). The problems encountered by MSEs, worsened by the COVID-19 pandemic, are not predicted at first, demanding the SMEs to innovate and even transform in any matter so the business will keep surviving.

The regulations applied by the government as to suppress Coronavirus spread make the community move to the digital world. The increasing uses of social media for business purposes is a strong indicator as to this matter. Therefore, the digitization process of MSMEs' businesses need to be carried out. It is admitted that digitalization is not something easy for MSMEs as they come across obstacles to expand the business such as limited internet access or capability to use technologies i.e. computers or mobile phones. Thus, because of the COVID-19 pandemic, the MSMEs' goods and service sales are decreasing.

According to the experts, in the era of Industry 4.0, MSMEs should incorporate information technology and the internet in their business (Matt \& Rauch, 2020). Experts also state that the COVID-19 pandemic accelerates the businessmen, including MSMEs, to get into the 4.0 Industry. It even occurs at present in several countries, such as Japan, which has begun its 5.0 Society. Verhoef, Broekhuizen, Bart, Bhattacharya, Qi Dong, Fabian \& Haenlein (2019) argue that digital transformation has a multidisciplinary nature involving strategic, organizational, information technology, supply chain, and marketing changes. The main purpose of digital transformation is to redesign the organizational business through digital technology introduction and beneficial achievements, such as productivity, cost reduction, and innovation improvements. The digital transformation leads to functional internet uses in designing, manufacturing, selling, displaying, and databased modeling management (Ulas, 2019). Ulas (2019) also found several hindrances experienced by MSMEs in adopting digital transformation, such as lack of budget, investment impossibility due to high investment and operational costs, incapability of understanding technology, having insufficient information about the digital standard, and lack of realizing the benefits of digitalization. COVID-19 pandemic causes many MSMEs to realize the importance of the internet and technology. One of them is to promote digital transformation that requires a more flexible business model change.

One of the approaches taken by the Ministry of Cooperation and Small and Medium Enterprises is to form business centres to encourage the development of MSMEs. Based on the Indonesian government regulation Number 17 of 2013 on the implementation of Law no. 20 of 2008 on MSMEs, centres are 'a particular area or location where there are several MSMEs that use the same raw materials or facilities, produce the same or similar products, and have prospected as centres 
for developing MSMEs.' The government has encouraged MSMEs to go digital such as the digital SMEs villages or 'Kampung UKM Digital program initiated by one of the state-owned enterprises or Badan Usaha Milik Negara (BUMN) PT. Telekomunikasi Indonesia (Telkom). Hundreds of digital SMEs villages have been established in several regions in Indonesia.

Slamet, Nainggolan, Roessobiyatno, Ramdani (2016) conduct research on digital SMEs villages by identifying the factors influencing SMEs' digitalization process using the SWOT matrix. Slamet et al. (2016) find that digital technology's adoption is proven to improve SMEs' performance. However, there are also obstacles faced by SMEs in the digitization process, especially related to the limited availability of information and communication technology infrastructure and the availability of resources, such as knowledge of SMEs about ICT, financial access, difficulties in obtaining raw materials, and online marketing constraints (Slamet et al., 2016)

\section{Identification of Influential Factors toward Digital Transformation}

Several studies have attempted to identify the influential factors in digital transformation for Micro, Small, and Medium Enterprises (MSMEs) both literature review and empirical. Generally, researchers group the factors into two: internal and external. However, other researchers identify the influential factors of digital transformation in a general manner meaning that they do not group them into internal and external factors. Some of them do not identify one factor, such as the internal or the external factor only. This article reviews literature and information from relevant previous findings to identify the influential factors of MSMEs' digital transformation. Then, the results are shown in a conceptual framework.

Verhoef et al. (2019) identify the influential factors of digital transformation necessities based on the literature review focusing on the external factor. Three external factors found trigger the needs of digital transformation, such as digital technology availability, digital competition, and digital customer behavior (Verhoef et al., 2019). Digital technology availability consists of online payment done via smartphones that encourages e-commerce development. It influences the corporate cost structures by optimizing the logistic flow and reducing the supply chain cost. Electronic commerce or e-commerce uses information technology via electronic system, such as the internet, television, and computer networks (Romindo, Muttaqin, \& Saputra, 2019). Hootsuite (2019) found that 107 million people purchased consumption goods via e-commerce-it increases by $5.9 \%$ of Indonesia's population in 2018. Also in 2019, 40\% of Indonesia's total population achieved e-commercial penetration on goods' consumptions where the market value of e-commerce consumers experienced an increase of $23 \%$. It shows that the opportunity of online business tends to continuously increase. On the other hand, digital technology causes competition to increase. In the retail sector, new digital technology disrupts sales to turn to digital corporations such as Amazon, Apple, and Facebook in the United States of America, Alibaba in China, and Tokopedia and Bukalapak in Indonesia. The last external factor is digital customers' behaviors that transform into responses toward the digital revolution, such as making their purchases 
to online shops. Hoffman \& Nofak (2017) states that the Internet of Things (IoT) can promote the revolution of customer experience. The consequences of digital technology use will challenge traditional business rules. Thus, if a corporation does not adapt to the changes, it will be less interesting for the customers and replaced by other corporations that apply technology.

Therefore, things should be prepared by MSMEs that promote business digitalization transformation as Eller, Alford, Kallmunzer, \& Peters (2020) mentions three main resources for SMEs to successfully promote business digitalization. They were information technology, employee skills, and digital strategy.

Information technology optimizes business processes to create values for customers and corporations (Verhoef et al., 2019) which cannot be separated from communication technology or known as Information and Communication Technology (ICT). It is necessary to digitize information and integrate a system for all manufacturing stages and product utilities (including logistic and supply), both inside or between corporations (Matt \& Rauch, 2020). However, IT's implementation significantly challenges MSMEs more than the large enterprises, as explained by the OECD (2017). SMEs' capability to quickly adopt new technology, learn, innovate, and optimize their production is limited by their small scales which then limits their capabilities to gain profits. Eller et al. (2020) claims that IT positively influenced SMEs' digitalization showing that IT resources, including cellular technology and social media, contribute to SMEs' digitalization.

Next, the employees' skills to adopt IT also influence the SMEs' digitization processes. Management in small enterprises is strongly correlated to the owner-manager characteristics and skills which are typically influenced by education and family background (Fuller-Love, 2006). Ownermanagers of SMEs make decisions on SMEs' marketing strategy based on knowledge, experiences, communication, and personal judgment (Carson \& Gilmore, 2000). Sousa \& Rocha (2019) similarly state that managers' higher awareness of required skills is needed which should continue running by re-considering the appropriate corporate strategies i.e. developing skills to respond to market challenges. Eller et al. (2020) show that employees' skills positively influence SMEs' digitalization. It means that SMEs' digitization processes depend on human capital, such as educated and skillful employees and employees' behaviors in the organization related to the applied norms and corporate values that influence the digital transformation process.

Finally, the applied digital strategy by SMEs should consider four dimensions digital transformation: technology utility, changing values of creation, organizational changes, and financial plan (Matt, Hess, \& Benlian, 2015). Technology utility discusses changing behaviours of corporations toward new technology and capabilities to use the technology. It allows corporations to decide using the appropriate technology to meet its business operation that excellently leads the market in terms of technology utility or only as a technology user. Additionally, changing values of creation are focused more on digital transformation strategy impacts towards corporate value chains, such as the deviation of digital activities from the promoted business. The deviation offers opportunities to expand and enrich the product and service 
portfolio, although there will be consequences and risks to deal with. Moreover, organizational changes refer to digital activities within the corporate structures. If changes in digital activities do not significantly impact a corporation, it can be settled by integrating the new operations into the existing corporate structure. However, if the emerging changes are significant, a special division must be established to settle the matters. Eller et al. (2020) showed that digital strategy positively influenced digitalization. Above all, these three elements can be transformed after considering the financial aspect. The financial aspect is important because it deals with the corporate capability to finance digital transformation that functions as encouragement or digital transformation power limiter. Eller et al. (2020) showed that digitalization positively influenced SMEs' financial performances.

Nguyen, Newby, \& Macaulay (2015), discussing IT adaptation of small enterprises, found two basic matters: (1) important reasons of adopting IT from the SMEs' owners or managers to create a better understanding with clear objectives of adopting IT and (2) capability of SMEs to judge factors that directly related to ITadopted environment to contribute to the IT management success. Nguyen et al. (2015) group five crucial-influential factors of successful and failed IT-adoptions. They are (1) organization consisting of management, staff, knowledge, recruitment, commitment, and contribution, (2) internal IT resource consisting of capability, skill, and capacity of SMEs' IT, (3) external IT consultant, with considerable knowledge and skills, who assist to develop strong IT for the SMEs, (4) supplier relations assist for greater efficiencies of the SMEs by collaborating and sharing knowledge among suppliers, and (5) customer relations, including the collaboration between customers and responses of customers' needs. The above factors have to be considered by managers or business owners to minimize MSMEs' risks while adopting IT. In sum, external IT, supplier, and customer relations can be categorized as external factors.

On the other hand, organization and internal IT source factors can be categorized as an internal factor. Nguyen et al. (2015) find those five factors positively contributed to the IT implementation success. The customer factor is then found to be the main motor of IT adoption for small enterprises. Small enterprises even become customer-oriented (Ozgener \& Iraz, 2006). Besides, corporations are demanded from fulfilling or even surpassing the customers' expectations by understanding their needs (Homburg, Wieseke \& Bornemann, 2009).

Tarute, Duobiene, Kloviene, Vitkauskaite, \& Varaniute (2018) identify digital transformation influential factors of SMEs into two parts based on literature reviews: internal and external factors. Tarute et al. (2018) reveal three internal factors influencing digital transformation: internal capability compatibility, internal resource compatibility, and business model changes. Firstly, internal capability consists of IT integration into corporate operational activities, internal corporate collaboration, and re-configuration capability. It also requires capability adjustment based on the business context and corporate-specific needs which allows corporations to successfully promote digital transformation. The adjustment is done by identifying longterm corporate targets including integrating information technology into corporate 
operational activities and collaborations between all internal corporation departments and skills to redesign an organizational structure during the digital transformation process. Secondly, corporate team capabilities to identify the human resource competence is crucial to promote digital transformation for internal resource compatibility. Additionally, it enables initiating communication, coordination, and continuous relationships with other corporations, including the existing service platform utility to successfully promote digitalization. The third internal factor is corporate capability to conduct business model changes consisting of a corporate value adjustment plan, customer interaction and collaboration.

Beside the internal factors, Tarute et al. (2018) also identify four potential external factors that significantly influence SMEs' digital transformation such as (1) external capability compatibility, (2) external resource compatibility, (3) government regulation, and (4) industrial factors.

The external capability compatibility deals with collaboration with two or more corporations to achieve common goals. It also deals with the capability to differentiate products or services based on the market needs. In addition, external resource compatibility refers to identifying the longterm objective compatibility among corporations and embedded trust among corporations. Moreover, factors such as government regulations, needs, and specific-industrial expectancies, including industrial readiness, also need to be considered. They are influential factors of corporate digital transformation processes.

On the other hand, Reis, Amorim, Melao, \& Matos (2018) categorize digital transformation into three elements: (1) technological - digital transformation based on new digital technology uses such as social media and cellular, (2) organizational digital transformation requiring changes in organizational process or new business model creation, and (3) social - digital transformation influencing all human life aspects such as improving customers' experiences. The summary of digital transformation influential factors is presented in Table 3.

Table 3. Internal and External Factors in Digital Transformation

\begin{tabular}{|c|c|c|c|}
\hline Authors & $\begin{array}{c}\text { The Investigated } \\
\text { Factors }\end{array}$ & Variables & Results \\
\hline $\begin{array}{l}\text { Verhoef et al. } \\
\text { (2019) } \\
\text { (Literature Review) }\end{array}$ & External Factor & $\begin{array}{l}\text { Digital Technology, } \\
\text { Digital Competition, } \\
\text { Digital Customer } \\
\text { Behavior. }\end{array}$ & $\begin{array}{l}\text { It emphasises more on } \\
\text { corporate digital source } \\
\text { necessities, organizational } \\
\text { structure, digital development } \\
\text { strategy, matrix, and objectives } \\
\text { of digital transformation. }\end{array}$ \\
\hline \multirow[t]{2}{*}{$\begin{array}{l}\text { Eller et al. (2020) } \\
\text { (Empirical) }\end{array}$} & \multirow[t]{2}{*}{ Internal Factor } & $\begin{array}{l}\text { Information Technology } \\
\text { (IT), } \\
\text { Employee Skills, } \\
\text { Digital Strategy. }\end{array}$ & $\begin{array}{l}\text { IT, employee skills, and digital } \\
\text { strategies positively influenced } \\
\text { SMEs' digitalization. }\end{array}$ \\
\hline & & Financial Aspect. & $\begin{array}{l}\text { Digitalization positively } \\
\text { influenced the financial } \\
\text { performance of SMEs. }\end{array}$ \\
\hline
\end{tabular}




\begin{tabular}{|c|c|c|c|}
\hline \multirow[t]{3}{*}{$\begin{array}{l}\text { Nguyen et al. (2015) } \\
\text { (Empirical) }\end{array}$} & Internal Factor & $\begin{array}{l}\text { Organizational, } \\
\text { Internal IT Resources. }\end{array}$ & $\begin{array}{l}\text { Organizational and internal IT } \\
\text { resources contribute } \\
\text { positively toward IT } \\
\text { implementation success. }\end{array}$ \\
\hline & \multirow[t]{2}{*}{ External Factor } & \multirow[t]{2}{*}{$\begin{array}{l}\text { External IT Consultant, } \\
\text { Supplier Relations, } \\
\text { Customer Relations. }\end{array}$} & $\begin{array}{l}\text { External IT consultant, } \\
\text { supplier, and customer } \\
\text { positively contribute to the IT } \\
\text { implementation success. }\end{array}$ \\
\hline & & & $\begin{array}{l}\text { Customer factor was the main } \\
\text { motor of the IT adoption } \\
\text { importance on a small scale } \\
\text { enterprise. }\end{array}$ \\
\hline \multirow[t]{7}{*}{$\begin{array}{l}\text { Tarute et al. (2018) } \\
\text { (Literature Review) }\end{array}$} & \multirow[t]{3}{*}{ Internal Factor } & $\begin{array}{l}\text { Internal Capability } \\
\text { Compatibility. }\end{array}$ & $\begin{array}{l}\text { Integration of IT into } \\
\text { corporate operational activity, } \\
\text { internal collaboration, and re- } \\
\text { configuration capability. }\end{array}$ \\
\hline & & $\begin{array}{l}\text { Internal Resource } \\
\text { Compatibility. }\end{array}$ & $\begin{array}{l}\text { Human resource competence } \\
\text { to identify the corporate team } \\
\text { and internal capability to } \\
\text { create communication and } \\
\text { corporate coordination. }\end{array}$ \\
\hline & & Business Model Changes. & $\begin{array}{l}\text { Corporate value adjustment } \\
\text { plan, improved customer } \\
\text { interaction, and collaboration. }\end{array}$ \\
\hline & \multirow[t]{4}{*}{ External Factor } & $\begin{array}{l}\text { External Capability } \\
\text { Compatibility. }\end{array}$ & $\begin{array}{l}\text { Inter-corporate collaboration } \\
\text { and customization. }\end{array}$ \\
\hline & & $\begin{array}{l}\text { External Resource } \\
\text { Compatibility. }\end{array}$ & $\begin{array}{l}\text { Alternative } \\
\text { strategy and inter-corporate } \\
\text { trust. }\end{array}$ \\
\hline & & Government Regulation. & $\begin{array}{l}\text { Government regulation about } \\
\text { digital transformation. }\end{array}$ \\
\hline & & Related Industrial Factors. & $\begin{array}{l}\text { Industrial readiness, } \\
\text { necessities, or industrial } \\
\text { specific expectancy. }\end{array}$ \\
\hline
\end{tabular}

Source: Adaptation from Verhoef et al. (2019); Eller et al. (2020); Nguyen et al. (2015); Tarute et al. (2018)

\section{The Perspectives of Capability and Ecosystem}

External and internal factors of capabilities encouraging SMEs' digital transformation can be seen from both ecosystem and capability perspectives. Li, Su, Zhang, Mao, \& Ji-Ye (2017) focus on the capability perspective: dynamic managerial capabilities and organizational capabilities. Dynamic managerial capabilities deal with SMEs' owners managerial skills to promote the digital transformation of their business ( $\mathrm{Li}$ et al., 2017). Helfat \& Martin (2015) group the dynamic managerial capabilities based on three main elements: managerial cognition, managerial social capital, and managerial human capital. Managerial cognition refers to personal managerial trust developed from the knowledge and understandings on a current event and predictions of future development. It also affects their decision-making. Additionally, 
managerial social capital deals with formal and informal relationships of managers with others that may be established to obtain sources and information. As a result, managers can take advantage of opportunities and market challenges and encourage re-configuration of the organizational resources. Thus, managerial social capital tends to be social-network empowerment. Last, managerial human capital includes knowledge, experience, skills, and proper managerial education on individual and team managerial levels (Helfat \& Martin, 2015).

On the other hand, organizational capability refers to more specific skills for organizational interests. In this case, SMEs entrepreneurs are among various organizations from different environments (Li et al., 2017). Thus, it is expected for SMEs entrepreneurs to have proper organizational skills with business target specifications. Organizational capabilities can be initiated by developing a competent organizational team which is expected to facilitate the SMEs to improve their capabilities to support digital transformation. After the competent organization is formed, it is important to increase capability of utilizing platforms and business development to support the digital transformation ( $\mathrm{Li}$ et al., 2017). The capability to use the platform is an organizational capacity to use the technological functionality of available digital platforms and adapt to innovations and changes. In this context, the MSMEs' capabilities to use digital platforms are important to promote MSMEs' successful digital transformation. It is primarily because the available digital platform allows MSMEs to obtain information and data, for example, customer preferences and efforts to stick closer to the customers. On the other hand, the business development capability refers to organizational capacity to obtain sources of service to advance the online business, both directly and indirectly, via the available digital platforms. Thus, MSMEs will have opportunities to use the offered digital platform services based on the applied requirements.

Helfat \& Martin (2015) mention that the dynamic managerial capability can impact cognitive, social capital, and human capital managerial on strategic changes and corporate performances. Helfat \& Martin (2015) conclude that managerial capabilities, cognition, social capital, and human capital will influence the realized corporate strategic changes and performances. Li et al. (2017) find in their qualitative research how dynamic managerial capability is correlated to digital transformation. Li et al. (2017) also review the dynamic managerial capability and the organizational capability of SMEs that can encourage digital transformation, especially e-commerce, with the support from digital platform providers. Moreover, $\mathrm{Li}$ et al. (2017) find qualified SMEs' behaviors in managerial cognition and social capital. Capability of cognitive and social capital managerial encouraged SMEs entrepreneurs to overcome digital transformation challenges. On the contrary, human capital managerial may not significantly encourage corporate digital transformation. On the other hand, organizational capability as in capability of utilizing platforms and business development is important for SMEs to successfully make digital transformation. Using the available digital platform allows SMEs to respond to marketing changes, keep a good rapport with the customers, and optimize and develop their businesses. 
The promoted corporate digital transformation process in the context of MSMEs can be seen from both capability and ecosystem perspectives. This article attempts to add the ecosystem perspective focusing on digital platform ecosystem management. The MSMEs' capabilities to control the digital platform in a digital ecosystem are essential because they influence the profit increases and realized innovations.

Dong, Hussain, \& Chang, (2007) do an integrative review on the concept of digital ecosystem which consists of two important parts: individual or organizational and ecosystem ecology. Individuals or organizations collaborate and cooperate to maintain their environment and play a role as the leader who leads followers in all groups. Both individuals or organizations can play double roles as suppliers and requesters at the same time. The suppliers play a role in providing the services while requesters deal with the required services. The individuals or organizations follow the general or specific regulations in the digital ecosystem. It is done by carrying out respective tasks to survive and reach the objectives of the digital ecosystem environment' which is to obtain profit.

On the other hand, the digital ecosystem environment covers opened environment (a transparent environment that has feedback), loosely coupled environment (free and opened relationships among individuals or organizations in the digital ecosystem), demand-driven environment (individuals or organization actively join the appropriate community based on the demand), domain clustered environment (environment of the places: individuals or organization that has same intention), self-organizing environment (individuals or organizations that can act, make decisions, and carry out the digital ecosystem tasks autonomously), and agentbased environment (the environment that is full of individuals, information technologies, interactive and sharing knowledge tools with supportive synergies between humans and organizations) (Dong et al., 2007).

Parker, Van Alstyne, \& Jiang (2008; 2016) conducted a review of platforms ecosystem based on the perspectives of platform's providers and digital platform service users or developers. Platform ecosystem consists of sponsoring platform providers, developers, and consumers. Platform providers have to consider strategies or innovations to attract the developers to their digital platforms. On the contrary, developers should be aware of weaknesses and strengths offered by each digital platform including regulations that will be applied to the digital platform users. Appropriate digital platform choice will influence the increased sales, market expansions, and targeted consumers since several digital platforms may not have certain specifications about their products or services. Digital platform users also need to consider the competition between the products or services in the digital platform since consumers have opportunities to compare the products based on prices, qualities, delivery, or payment process to their preferences. The digital platform will create opportunities for users to get into the digital ecosystem.

Hein, Schreieck, Riasanow, Setzke, Wiesche, Bohm, \& Krcmar (2019) mention three main cores of the digital platform ecosystems: platform ownership, valuecreating mechanisms, and complementor autonomy. It is expected that by considering 
these core elements of the digital platform ecosystems it can facilitate corporations to perceive technical features and value creation, complementary interaction with the ecosystem, the capability to obtain values within digital ecosystem platforms, and decision making whether to create or to combine digital platform ecosystems.

MSMEs' significant challenges due to the COVID-19 pandemic are to deal with the changes in customers' needs, from offline into online due to physical distancing and Large-Scale Social Restriction policies. Therefore, digital transformation has to be carried out by MSMEs' entrepreneurs, utilizing various available program services from the government or cooperation with stakeholders. It is to support the MSMEs' accelerations in the digital transformation process through the existing digital platform so these MSMEs can get into the digital ecosystem. Thus, it is expected to have many digitized MSMEs, ranging from the raw material supplier, packaging, delivery, and payment services, sales, and product marketing. Thus, MSMEs need intelligence to respond to the changes immediately and seriously. They are expected to actively react product and technological innovations, to business opportunities such as re-arranging the mindset, spirit to move on, marketing, and new ways of running businesses. Based on the above explanation, Figure 1 presents the conceptual framework of this article.

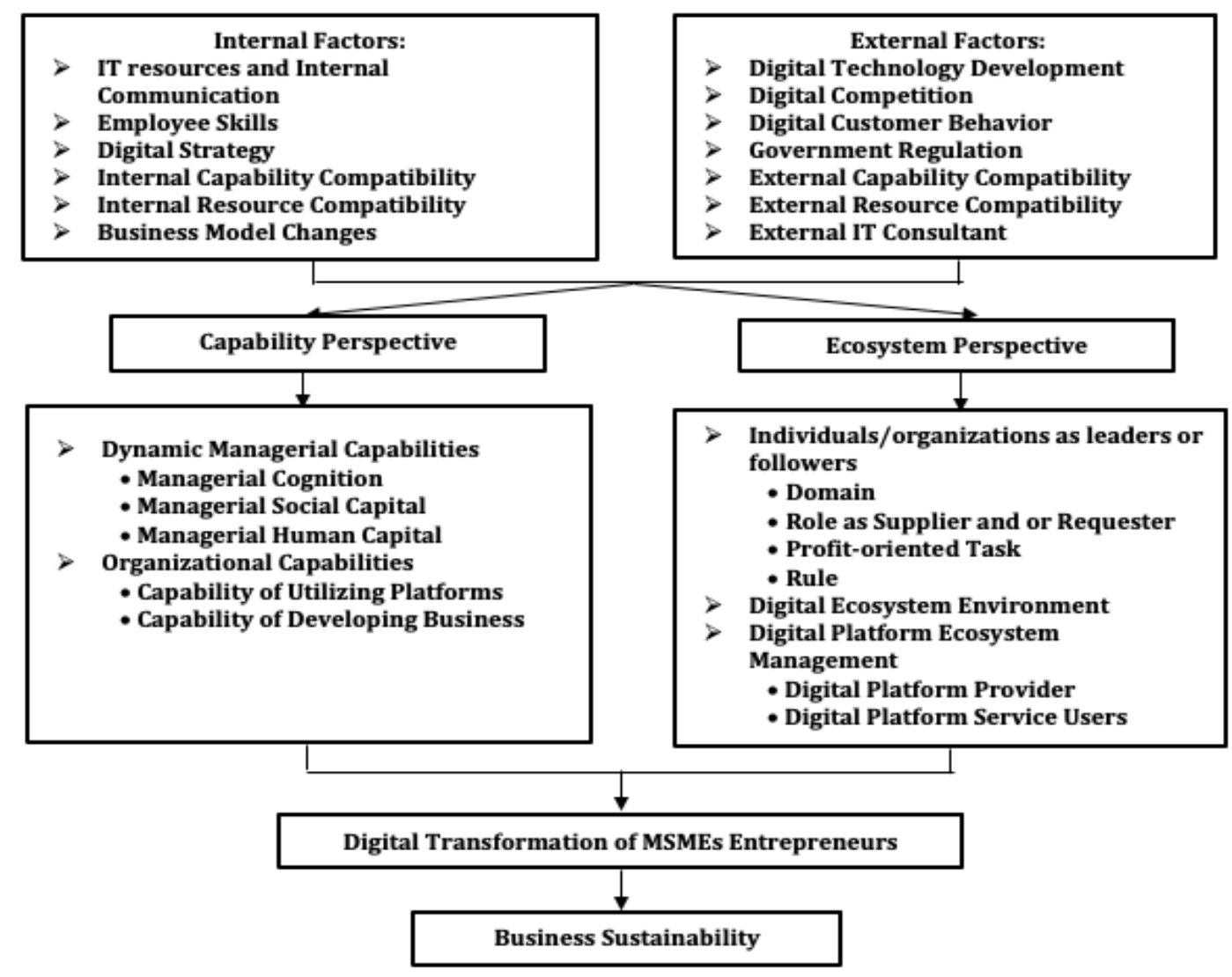

Figure 1. Digital Transformation Conceptual Frameworks of MSMEs Entrepreneurs Source: Processed by the Authors (2020) 


\section{CONCLUSION}

This article identifies the determinant factors of digital transformation on MSMEs, grouped into internal and external factors. Three external factors triggering the need for digital transformation for MSMEs are digital technology availability, competition, and customer behavior (Verhoef et al., 2019). Eller et al. (2020) mentioned three main resources of SMEs in promoting business digitalization: information technology, employees' skills, and digital strategy. These resources can be categorized as the internal factors of SMEs. Eller et al. (2020) also find that IT, employees' skills, and digital strategies positively influenced SMEs' digitalization. The financial aspect is also important because it deals with the corporate capability to finance the efforts to transform digitally that function as encouragement or digital transformation power limiter. Eller et al. (2020) further show that digitalization positively influenced SMEs' financial performances.

Nguyen et al. (2015) group five crucial-influential factors of successful and failed IT-adoptions: organization, internal IT resource, external IT consultant, supplier relations, and customer relations. These factors are necessarily to be considered by managers or business owners to minimize MSMEs' risks while adopting IT. External IT consultant, supplier, and customer relations can be categorized as external factors whereas organization and internal IT resources can be categorized as internal factors. Nguyen et al. (2015) find those five factors positively contributed to the success of IT implementation. The customer factor is then found to be the main motor of IT adoption for small enterprises. Tarute et al.
(2018) based on literature reviews divide the influential factors of digital transformation for SMEs into two parts: internal and external factors. They reveal three internal factors influencing digital transformation: internal capability compatibility, internal resource compatibility, and business model changes. On the other hand, four potential external factors significantly influence the SMEs' digital transformation such as external capability compatibility, external resource compatibility, government regulation, and industrial factors.

The capabilities of external and internal factors to encourage MSMEs' digital transformation can be viewed from both ecosystem and capability perspectives. The capability perspective focuses on dynamic managerial capabilities emphasizing on three main cores: managerial cognition, managerial social capital, and managerial human capital (Helfat \& Martin, 2015). Li et al. (2017) emphasize dynamic managerial capabilities by adding organizational capability initiated by the competent organizational team, capabilities to use the platform, and business development to support digital transformation. Helfat \& Martin (2015) conclude that managerial capabilities including managerial cognition, social capital, and human capital will influence the realized corporate strategic changes and performances. Li et al. (2017) find qualified SMEs' behaviors in managerial cognition and social capital that are expected to be able to overcome digital transformation challenges. On the contrary, managerial human capital may not significantly encourage corporate digital transformation. However, organizational capability shown through the capability to utilize platforms and business development is important to 
encourage the success of SMEs' digital transformation.

This article also focuses on the management of the digital platform ecosystems as a requirement of MSMEs' digital transformation from the perspective of ecosystem. The MSMEs' capabilities to control the digital platform in a digital ecosystem are important because they influence the profit increases and realized innovations. Dong et al. (2007) do an integrative review on the concept of digital ecosystem which consists of two main parts: individuals or organizations, and ecosystem environments. The individuals or organizations collaborate and cooperate to maintain their environment by acting as leaders that lead the followers in groups. Both individuals or organizations can play double roles as suppliers and requesters at the same time. The individuals or organizations follow general or specific regulations in the digital ecosystem. It is done by carrying out tasks accordingly to survive and reach the objectives of the digital ecosystem environment which is to

\section{REFERENCES}

Bagus, A., Arif., Fathin, A., Ranggajati, A., dkk. (2020). Melindungi Pekerja Rentan di Masa (dan Pasca) Pandemi COVID19. Available at: https://map.ugm.ac.id/wpcontent/uploads/sites/290/2020/04 /Melindungi-Pekerja-Rentan-diMasa-dan-Pasca-Pandemi-Covid-19kompres.pdf. Diakses 9 Agustus 2020.

Bank Indonesia. (2010). Krisis Global dan Penyelamatan Sistem Perbankan Indonesia. Available at: obtain profit. Parker et al. (2008; 2016) review platforms ecosystem based on the perspectives of platform's providers and digital platform service users or developers.

By having these MSMEs getting into the digital platform ecosystem, they are expected to accelerate the MSMEs entrepreneurs to promote digital transformation. Thus, the government has to guide the MSMEs to accelerate their readiness and to transform their businesses from offline to online. The government can also provide facilities, such as a program launching, to encourage MSMEs to go digital and join several digital platform corporations and MSMEs' product purchases. Having the MSMEs getting into digital platform corporations will facilitate the digital transformation of MSMEs and provide opportunities to get into the digital platform ecosystem. Therefore, the government has to encourage digital transformation and stimulates the MSMEs to keep their businesses running. It eventually can accelerate the national economy recovery due to COVID-19.

https://www.bi.go.id/id/publikasi/lain/lai nnya/Pages/buku krisis global 180 110.aspx. Diakses 9 Agustus 2020.

Bank Indonesia. (2020). Sinergi, Transformasi, dan Inovasi Menuju Indonesia Maju. Laporan Perekonomian Indonesia 2019. Available at: https://www.bi.go.id/id/publikasi/l aporantahunan/perekonomian/Documents /2_LPI2019_TINJAUANUMUM.pdf. Diakses 20 Agustus 2020. 
BPS. (2018). Potensi Usaha Mikro Kecil. Available at: https://www.bps.go.id/publication/ 2018/12/31/e3e59cd2b44229814b5a 7176/potensi-usaha-mikro-kecilsensus-ekonomi-2016.html. Diakses 11 Agustus 2020.

BPS. (2020). Laporan Bulanan Data Sosial Ekonomi. Availabe at: https://www.bps.go.id/publication/ 2020/08/14/e7fa20877e90b61f1144 c7ad/laporan-bulanan-data-sosialekonomi-agustus-2020.html. Diakses 11 Agustus 2020.

Carson, D., and A. Gilmore. (2000). SME Marketing Management Competencies. International Business Review, 9(3), 363-382.

Damuri, Y., Hirawan, F. (2020). Mengukur Dampak. COVID-19 pada Pertumbuban Ekonomi dan Perdagangan Indonesia 2020. Available at: https://csis.or.id/publications/meng ukur-dampak-covid-19-padapertumbuhan-ekonomi-danperdagangan-indonesia-2020/. Diakses 15 Agustus 2020.

Dong, H., Hussain, F. K., Chang, E. (2007). An Integrative View of the Concept of Digital Ecosystem. Proceedings. International Conference Networking and Services, ICNS 2007, 19-25 June 2007.

Djalante, R., Lassa, J., Setiamarga, D., Sudjatma, A., et al. (2020). Review and Analysis of Current Responses to COVID-19 in Indonesia: Period of January to March 2020. Journal Progress In Disaster Science, (Online), Volume 6, April 2020, Artikel 100091, (https://doi.org/10.1016/j.pdisas.20 20.100091), diakses 17 Agustus 2020.
Eller, R., Alford, P., Kallmunzer, A., Peters, M. (2020). Antecedents, consequences, and challenges of small and medium-sized enterprise digitalization. Journal of Business Research, Volume 112, May 2020, 119-127.

Fuller-Love, N. (2006). Management Development in Small Firms. International Journal of Management Reviews, 8(3), 175-190.

Guerrieri, V., Lorenzoni, G., Straub L., Werning, I. (2020). Macroeconomic Implications of COVID-19: Can Negative Supply Shocks Cause Demand Shortages?. Available at: https://www.nber.org/papers/w269 18. Diakses 15 Agustus 2020.

Hinjoy, S., Tsukamaya, R., Chuxnum, T., Masunglong, W., et al. (2020). SelfAssessment of the Thai Department of Disease Control's Communication for International Response to Covid19 in the Early Phase. International Journal of Infectious Diseases, Volume 96, July 2020, 205-210.

Hein, A., Schreieck, M., Riasanow, T., Setzke, D.S., Wiesche, M., Bohm, M., Krcmar, H. (2019). Digital Platform Ecosystems. Electron Markets, 30, 8798.

Helfat, C. E., \& Martin, J.A. (2015). Dynamic Managerial capabilities: Review and assessment of managerial impact on strategic change. Journal of Management, 41 (5), 1281-1312.

Hoffman, D.L., Novak, T.P. (2017). Consumer and object experience in the internet of things: An assemblage theory approach. Journal of Consumer Research, Vol. 44(6), 1178-1204. 
Hootsuite. (2019). Digital 2019 Indonesia (January 2019), Data reportal. Available at:

https://www.slideshare.net/DataRe portal/digital-2019-indonesiajanuary-2019-v01 ?qid $=6 a 354 b 6 b-$ f8c3-41c2-99ae$\mathrm{ffb} 2 \mathrm{c} 9 \mathrm{f} 90 \mathrm{e} 3 \mathrm{a} \& \mathrm{v}=\& \mathrm{~b}=\&$ from_search $=1$. Diakses 15 Agustus 2020 .

Homburg, C., Wieseke, J., Bornemann, T. (2009). Implementing the Marketing Concept at the Employee-Customer Interface: The Role of Customer Need Knowledge. Journal of Marketing, Vol. 73, No. 4, 64-81.

Jaakkola, E. (2020). Designing conceptual articles: four approaches. AMS Review, 10, 18-26.

Johns Hopkins University. (2020). Covid-19 Dashboard by the Center for Systems Science and Engineering (CSSE). Available at: https://coronavirus.jhu.edu/.

Diakses 9 Agustus 2020.

Kementerian koperasi dan Usaha Kecil dan Menengah (KemenkopUKM). (2018). Perkembangan Data Usaba Mikro, Kecil, Menengah (UMKM) dan Usaba Besar (UB) Tabun 2017-2018. Available at: http://www.depkop.go.id/uploads/1 aporan/1580223129_PERKEMBAN GAN $\% 20$ DATA $\% 20$ USAHA $\% 20 \mathrm{M}$ IKRO,\%20KECIL, \%20MENENG AH $\% 20(\mathrm{UMKM}) \% 20$ DAN $\% 20$ USA HA $\% 20 B E S A R \% 20(U B) \% 20$ TAHU N\%202017\%20-\%202018.pdf.

Diakses 9 Agustus 2020.

Kementerian koperasi dan Usaha Kecil dan Menengah

(KemenkopUKM). (2020). Cooperative Siap Bersama KUMKM Lawan Corona. Edisi No. 02/ April 2020. Available at: http://www.depkop.go.id/uploads/l
aporan/1592638534_Cooperative $\% 2$ 0April\%202020\%20v2.pdf. Diakses 11 Agustus 2020.

Kementerian Kesehatan (Kemenkes) RI. (2020). Pedoman Pencegaban dan Pengendalian CoronaVirus Disease (COVID-19). Available at: https://covid19.go.id/p/protokol/p edoman-pencegahan-danpengendalian-coronavirus-diseasecovid-19-revisi-ke-5. Diakses 15 Agustus 2020.

Kemenkeu. (2020). Tinjauan Ekonomi, Kenangan, \& Fiskal: Menjaga Ekonomi Nasional di Tengah Pandemi Covid-19. Available at: https://fiskal.kemenkeu.go.id/publik asicetak/tekf/2020/tekf2/files/TEKF EdisiII2020.pdf. Diakses 15 agustus 2020.

Li, L., Su, F., Zhang, W., Mao, Ji-Ye. (2017). Digital Transformation by SME Entrepreneurs: A capability perspective. Journal Info System, 28, 1129-1157.

Matt, C., Hess, T., \& Benlian, A. (2015). Digital transformation strategies. Business and Information Systems Engineering, 57(5), 339-343.

Matt, D., \& Rauch, E. (2020). SME 4.0: The Role of Small-and Medium-Sized Enterprises in the Digital Transformation. In Edited by Matt, D., Modrak, V., Zsifkovits, H, The Industry 4.0 for SMEs Challenges, Opportunities, and Requirements. Switzerland: The Palgrave Macmilan. Nguyen, T. H., Newby, M., \& Macaulay, M. J. (2015). Information technology adoption in small business: Confirmation of a proposed 
framework. Journal of Small Business Management, 53(1), 207-227.

OECD. (2017). Key issues for digital transformation in the G20. Available at: https://www.oecd.org/g20/keyissues-for-digital-transformation-inthe-g20.pdf. Accessed 25 August 2020.

Ozgener, S., \& Iraz, R. (2006). Customer Relationship Management in SmallMedium Enterprises: The Case of Turkhish Tourism Industry. Journal Tourism Management, 27, 1356-1363

Parker, G., \& Van Alstyne, M. (2008). Managing Platform Ecosystems. Proceedings. International Conference on Information Systems, ICIS 2008, January.

Parker, G., Van Alstyne, M., Jiang, X. (2016). Platform Ecosystems: How Developers Invert the Firm. Research Paper. Boston University Questrom School of Business, 17 August 2016.

Peraturan Pemerintah Republik Indonesia Nomor 17 Tahun 2013 tentang Pelaksanaan Undang-Undang Nomor 20 Tahun 2008 tentang Usaha Mikro, Kecil dan Menengah.

Reis, J., Amorim, M., Melao, N., Matos, P. (2018). Digital Transformation: A Literature Review and Guidelines for Future Research. Dalam Rocha, A., Adeli, H., Reis, L.P., Costanzo, S. (Eds), Trends and Advances in Information Systems and Technologies (hlm. 411-421). Switzerland: Springer.

Romindo, Muttaqin, Saputra, D.H., dkk. (2019). E-Commerce: Implementasi, Strategi dan Inovasinya. Medan: Yayasan Kita Menulis.
Suryahadi, A., Izzati, R., Suryadarma, D. (2020). Estimating the Impact of Covid-19 on Poverty in Indonesia. Journal Bulletin of Indonesian Economic Studies, Vol. 56, No. 2, 175-192.

Sousa, M. J., \& Rocha, A. (2019). Skills for disruptive digital business. Journal of Business Research, 94, 257-263.

Slamet, R., Nainggolan, B., Roessobiyatno, Ramdani, H., dkk. (2016). Strategi Pengembangan UKM Digital dalam Menghadapi Era Pasar Bebas. Jurnal Manajemen Indonesia, Vol. 16, No. 2, 136-147.

Tarute, A., Duobiene, J., Kloviene, L., Vitkauskaite, E., \& Varaniute, V. (2018). Identifying Factors Affecting Digital Transformation of SMEs. Proceedings. The $18^{\text {th }}$ International Conference on Electronic Business, ICEB, Guilin, China, December 2 June 2018.

Ulas, D. (2019). Digital Transformation Process and SMEs. Journal Procedia Computer Science 158, 662-671.

Verhoef, P. C., Broekhuizen, T., Bart, Y., Bhattacharya, A., Qi Dong, J., Fabian, N., \& Haenlein, M. (2019). Digital transformation: A multidisciplinary reflection and research agenda. Journal of Business Research, (Online), (https://www.sciencedirect.com/scie nce/article/pii/S0148296319305478, diakses 12 Agustus 2020.

WHO (World Health Organization). (2020). WHO Statement on Novel Coronavirus in Thailand. Available at: https://www.who.int/newsroom/detail/13-01-2020-whostatement-on-novel-coronavirus-inthailand. Accessed 9 August 2020. 